\title{
Increasing Students' English Language Learning Levels via Lesson Study
}

\author{
Remzi Y. Kıncal ${ }^{1}$, Ceyhun Ozan ${ }^{2} \&$ Duygu İleritürk ${ }^{2}$ \\ ${ }^{1}$ Faculty of Education, Çanakkale Onsekiz Mart University, Çanakkale, Turkey \\ ${ }^{2}$ Kazim Karabekir Faculty of Education, Atatürk University, Erzurum, Turkey \\ Correspondence: Ceyhun Ozan, Kazim Karabekir Faculty of Education, Atatürk University, Erzurum, Turkey.
}

Received: July 13, 2019 Accepted: August 18, 2019 Online Published: August 20, 2019

doi: 10.5539/elt.v12n9p88 URL: https://doi.org/10.5539/elt.v12n9p88

This paper was presented at the 5th International Curriculum and Instruction Congress held on 26-28 October 2017, in Muğla, Turkey.

\begin{abstract}
The study aims to develop students' higher cognitive skills e.g. analysis, synthesis and assessment and to increase their academic successes by reflecting their cognitive skills in psychomotor skills in practice with the help of lesson study. Therefore, the aim of the study is to increase students' English as a foreign language learning level. Action research was used in the study. "English Achievement Test" and "Semi-Structured Interview Form" developed by the researchers were used as data collection instruments. English achievement test was used as pre-test and post-test to define students' English language levels, and semi-structured interview form was used to determine teachers' views about lesson study practice. According to research result, lesson study has increased students' learning levels significantly. Moreover, teachers stated that lesson study was highly beneficial and affected their professional development in a positive way. It was stated by teachers in the study that lesson study had the teachers a chance to observe and assess their teaching qualities and so, it made the students' learning levels increase significantly. Furthermore, all of the teachers agreed that lesson study as an in-service training model could be an approach used for both other lessons and nationally.
\end{abstract}

Keywords: English language learning, learner-centered teaching, lesson study, professional development, teaching foreign language

\section{Introduction}

The competition among countries has increased more via scientific changes and technological developments in the recent days. The most important element of globalization is learning product, which enables the countries to show themselves internationally. In this manner, international exams e.g. PISA and TIMSS, which enables the countries to compare themselves with each other, have gained much more importance. Educational assessment is significant for both European countries and other countries. International standard assessments like PISA are important to state the countries' levels internationally and to compete with their performances globally. Students' performances are assessed through almost the same aims in each country. Assessment aims are formed according to success in curriculum aims, curriculum outcomes and learning outcomes (Luukkainen et al., 2016). Accordingly, PISA assesses 15-year-old students in terms of mathematics literacy, reading skills and science literacy. Literacy is described as a capacity for practicing students' knowledge and skills, and to analyze the problems occurred in different contexts, to reason, to communicate effectively, to interpret and product different solutions to the problems.

Bulle (2011) defines that literacy is an assessment of students' skills that cope with problems in both school and real life situations. However, problems presented in schools should be parallel with real life problems. When Turkey PISA results especially in 2003 - 2015 have been analyzed, it has been seen that there is no a statistically significant positive development. Therefore, PISA, significant for assessing the countries' educational levels internationally, is highly significant to define and revise countries' educational systems. Moreover, countries could develop and use new teaching and learning methods and techniques according to PISA results. There are many approaches for supporting both students' learnings and teachers' professional developments. Lesson study 
is the leading one in many countries such as Japan and Singapore, which are the most important educational leader countries. Lesson study not only brought out as a professional development approach in Japan but also it aims to develop students' learning and teaching.

Lesson study focuses on cooperative planning, teaching, observation and development of the lesson by reasoning within different aspects (Halvorsen \& Lund, 2013). Lesson study, which is called as "ders imecesi" in Turkish literature, is a research-based approach that is practiced in Japan, Singapore and Hong Kong whose educational systems prove themselves internationally and nationally. Lesson study is also a specialized action research that increases students' successes and has practical output with the aim of enabling teachers to develop their own professional development. Moreover, it is an in-class research that enables teachers to search teaching and learning in real class context. Lesson study is also a process that includes reported works e.g. how teachers plan their lessons, explain and experience their teaching, and moreover what they learn and teach in the class (Ono \& Ferreire, 2010). Lesson study practices, which are called as on-the-job training in terms of teachers' professional development, are circular research processes that reorganize teaching and learning periods, thereby being analyzed the limitations of the lesson by 4 or 6 teachers so as to succeed the aims of the lesson. Furthermore, lesson study is self-authorized and democratic process. All participants into the lesson study all together when they decide, and contribute themselves equally (Stepanek et al., 2007).

Therefore, lesson study aims to develop learners' learning via teacher development and teachers' in-service training practices especially who work in the schools whose successes are at low levels. It is seen that students' achievements are at low levels especially in mathematics and English courses in Turkey. It could be said that PISA 2015 participant students' low achievements in reading skills literacy are related to deficiencies in higher cognitive and psychomotor skills e.g. analysis, synthesis and assessment in addition to reading and writing skills of students in foreign language. Singapore and Japan, in which lesson study is used intensely, have shown their performances at higher levels in PISA 2012, 2015 and TIMSS 2015 that enable many countries to compare with themselves and each other. There are lots of much research showing to increase students' achievement at higher level thinking skills, learning skills and academic successes (Borko \& Puntam, 1995; Grosso de Leon, 2001; Lucenario et al., 2016; Midgette et al., 2018; Phillips, 2003; Schipper et al., 2018; Vogt \& Rogalla, 2009; Wood \& Cajkler, 2018). Lesson study process consists of three sections e.g. planning (preparation), practice (observation) and assessment (discussion and reflection). It also consists of different sections. Five-section lesson study process is like: 1) Teachers plan the lesson cooperatively. 2) A teacher teaches the lesson. 3) Teachers reorganize the lesson according to the observation about the lesson. 4) The teacher teaches the lesson again. 5) Teachers discuss and reflect the lesson reorganized and taught again (Halvorsen \& Lund, 2013; Nami et al., 2016). Planning section begins with topic selection and continues to decide teaching materials and organize lesson plans. Teachers study cooperatively to succeed their aims. Preparation of teaching materials is a teacher-friendly process that teachers clarify uncertain unites and the data about teaching unite is justified. When the lesson plan is prepared, teachers should take students' learning needs, readiness and misconceptions into consideration. After planning section, a teacher teaches the lesson according to lesson plan. Each observer gets the lesson plan. The observers observe the lesson according to lesson study aim (Ono \& Ferreira, 2010).

According to Cheng \& Pan's (2019) study, using lesson study model could be said to have a higher impact on especially English language teacher. Lesson study helps teachers demonstrate different aspects of their identity. Moreover, lesson study enables teachers to improve their own English language skills e.g. speaking, reading and listening.

Turkey curriculum focus has transformed traditional educational perspective into learner-centered perspective since 2004, and therefore it focuses on development of real life skills thereby academic education. In this manner, basic skills have been constituted in revised curriculum such as critical thinking, creative thinking, communicative skill, and research skill, skill of using informatics technologies, entrepreneurship, and problem solving skill and speaking Turkish language effectively and in a good way. Language skill provides for communicating people with each other and it enables this communication to maintain in different forms (Özdemir-Ateş, 2006). English as a foreign language is taught in the curriculum since 2th grade by means of revising curriculum $4+4+4$ in Turkey. Many regulations on foreign language teaching have been made with the help of European Union educational policies. English courses as a foreign language are taught intensely in the curriculum in the manner of European Union foreign language education policies (Sağlam et al., 2011). Therefore, it is seen that students have some difficulties in speaking skills although teaching English as a foreign language is made intensely. Cooperative learning, drama and performance based assessment are used to eliminate these difficulties in foreign language teaching (Sağlam et al., 2011). Communicative teaching approach is used in the scope of English as a foreign language teaching. According to this approach, mother language is 
not used while teaching foreign language, and so the language teaching focuses on original works belonging to taught language and its culture. Moreover, learners realize not only the language is a course or lesson but also it is a need for communication (Özdemir-Ateş, 2006).

Although foreign language is a communicative tool, this aspect of a language is ignored in the practice. It is seen that there are some difficulties especially in teaching foreign language (Acat \& Demiral, 2002; Aydın et al., 2017; Coşkun-Demirpolat, 2015; Ege, 2011; Haznedar, 2004; Işı1k, 2008; Oflaz, 2015). Accordingly, the study aims to develop students' higher cognitive skills e.g. analysis, synthesis and assessment and to increase their academic successes by reflecting their cognitive skills in psychomotor skills in practice with the help of lesson study. In this manner, it is thought that the study would contribute to the related literature because there is limited research about lesson study in foreign language teaching and moreover, lesson study, one of the professional development models, contribute to develop foreign language teaching.

\subsection{Research Questions}

The aim of the study is to increase students' English as a foreign language learning level. The problems of the study are below according to this aim.

1) Does lesson study increase students' English as a foreign language learning level significantly?

2) What are the opinions of English language teachers about lesson study?

\section{Method}

\subsection{Research Design}

Action research was used in the study. According to Johnson (2012), action research is a period, which tries to solve real school life's problems systematically. Action research can be used instead of traditional in-service professional training of teachers, and it could be used for the deficiencies between educational research and teaching practices (Wilson, 2013). Action research is a circular and spiral process that involves people's practices who focus on changes and developments, collect and analysis the data systematically and reflectively, and also prepare and practice new action plans (Gürgür, 2016). Therefore, action research is suitable with research questions and aim. Lesson study, which aims to develop students' learning capacities with teachers' cooperative, is highly acceptable for action research.

\subsection{Participants}

This study was conducted in a high school that is socioeconomically at low level in Erzurum at spring term. The sample of the study was consisted of twenty-four students studying at 9th grade and five English language teachers. Fourteen students were male and ten students were female. The participant teachers into the study were female, and their professional seniority average was 5.8. This school was selected for the study due to practicing lesson study into unsuccessful schools according to the related literature. Because this school's general average point was so low according to Turkish Ministry of Education reports. Moreover, criteria sampling method was used to select the sample. Accordingly, these criteria are the general point average of courses and voluntariness of students and teachers.

\subsection{Instruments}

"English Achievement Test" and "Semi-Structured Interview Form" developed by the researchers were used as data collection instruments. English achievement test was used as pre-test and post-test to define students' English language levels, and semi-structured interview form was used to determine teachers' views about lesson study practice. The achievement test consisted of 32 questions - 14 multiple-choice questions and 18 open-end questions. While developing the test, Pisa questions were analyzed and accordingly, 50 questions were prepared to assess students' higher cognitive skills. Three lecturer who work at Curriculum and Instruction departments and five English language teachers made the test's context validity. According to experts' views, the test, which includes fifty questions, was implemented to 80 students studying at 10th grade as a pre-test. After pre-test, item analysis was done, and however 30 questions were chosen whose discrimination indexes are above .30 . KR-20 reliability coefficients of English achievement test are .85 for pre-test and moreover, .88 for post-test.

Semi-structured interview form developed by researchers was used to collect qualitative data. Expert opinion was applied to make context validity. Interview forms was reorganized according to four lecturer working at Curriculum and Instruction department. Interview form consisted of two questions. Interviews lasted 7 minutes averagely and tape recording was done.

\subsection{Data Collection Procedures}


The implementations in the study were included unites of spring term of 9th grade. The courses were prepared according to the curriculum standards of Turkish Ministry of Education, they were students-centered and constructive. In the scope of lesson study teachers gathered once a week and they prepared next week lesson plan altogether. All the research lessons were planned by two researchers and teachers. The plans focused on the weaknesses of the students so that they were developed. The developed lesson plan was implemented as a pre-practice by one of three teachers, and however other teachers took their places as observers in the lesson. In the next step, teachers assessed the observed lessons and revised the lesson plan accordingly. According to the observations, the lesson plan was re-planned and practiced into the sample. The revised lesson plan was implemented in the study group. Therefore, students in the study group were practitioners of the lesson plan. Moreover, teachers in the study had a role as both observer and designer of lesson plans. The researchers were experts of the lesson study model. The researchers were also observers of the lessons as well as experts.

\subsection{Data Analysis}

SPSS 23 was used for qualitative data analysis. Firstly, normality assumptions were analyzed whether to determine which test would be used. Accordingly, Skew and Kurtosis coefficients were analyzed, and however scatter plot was reviewed. Control and experimental groups' pre-test skew coefficients respectively were .-17 and .30, and moreover post-test skew coefficients were --18 and .48. Control and experimental groups' pre-test kurtosis coefficients were respectively .58 and .67 , and post-test kurtosis coefficients were .49 and .68 . Therefore, it could be said that distribution was applied to normality assumptions. Depended t-test was used to analyze quantitative data to determine whether students' learning levels improve. Descriptive analysis technique was used for qualitative data analysis. According to descriptive analysis technique, teachers' views were transformed into codes, and they were presented in tables. Moreover, direct references of teachers' views were often reported in data analysis. Two researchers analyzed qualitative data separately. Agreement percentage formula, developed by Miles and Huberman (2015), was used for reliability of analysis. Agreement percentage formula is that "Reliability $=$ Agreement $/($ Agreement + Divergence $) * 100 "$. Accordingly, agreement percentage of the analysis is 0.95 . It shows that the analysis is reliable.

\section{Results}

Paired samples t-test was done to determine students' learning levels, and accordingly the results of the test are shown Table 1.

Table 1. The results of pre-test and post-test about learning levels

\begin{tabular}{lllllll}
\hline Test & $\mathrm{n}$ & $\overline{\mathrm{x}}$ & $\mathrm{Sd}$ & $\mathrm{df}$ & $\mathrm{t}$ & $\mathrm{p}$ \\
\hline Pre-test & 24 & 9.46 & 5.00 & 23 & -5.022 & $.00^{*}$ \\
Post-test & 24 & 15.08 & 4.97 & 23 & & \\
\hline
\end{tabular}

According to Table 1, there is a significant difference between pre-test and post-test results of the students $(\mathrm{t}=-5,022 ; \mathrm{p}<0.05)$. The achievement test averages of students increased from 9.46 to 15.08 . It shows that lesson study practices have increased students' English learning levels significantly. Table 2 and the descriptions at below are related to teachers' views about lesson study.

Table 2. The assessment of teachers about lesson study

\begin{tabular}{lll}
\hline Category & $\mathrm{f}$ & Codes \\
\hline & 5 & Increasing learning level \\
& 5 & Developing lesson according to students \\
A1 & 4 & Students enjoying the lesson \\
& 4 & Increasing professional skills of teachers \\
& 3 & The problems about arranging time of teachers \\
\hline
\end{tabular}

According to Table 2, it is seen that teachers' views about lesson study are parallel to each other. All teachers stated that lesson study enables teachers to develop lessons for students and to increase students' learning levels. 
Four teachers stated that students had a good time in the lesson thanks to lesson study practice, and lesson study also contributed to their professional development significantly. Three of four teachers figured out that they had a problem- as a negative feature of lesson study- that is the time teachers gathered for practicing lesson study cycle. It has been seen exactly at teachers' one-to-one interviews.

T1: I saw that students had much more fun while doing these activities. In other words, I figured out that they learned much more while they had fun. I thought that this situation was related mainly to lesson study activities.

T2: I thought that students' learning levels had increased significantly thanks to lesson study. However, it also contributed to our professional skills significantly.

T3: ... planning lesson cooperatively with other teachers and you made a higher contribution to the lesson quality.

T4: ... I thought that getting used to lesson study more efficient for us. Studying with other teachers cooperatively made a significant contribution to us.

T5: ... I thought that it made a significant contribution to my professional development. I learned so much thing in this process. It was very important to observe other teachers' teaching.

Table 3 and other descriptions are about the views of teachers about lesson study feasibility in Turkey.

Table 3. The views of teachers about lesson study feasibility in Turkey

\begin{tabular}{lll}
\hline Category & $\mathrm{f}$ & Codes \\
\hline A2 & 5 & It is practical for all lessons. \\
\hline
\end{tabular}

According to Table 3, all of the teachers agreed that lesson study was beneficial to them and, it could be a practical approach for all lessons in Turkey. The exact quotations from teachers are below:

T1: It could be practical for all lesson in Turkey, and it should be practiced.

T2: If the teachers have positive approach about it, it can be practiced in all lessons.

T3: If the teachers adapt lesson study, it can be practiced in all lessons. There is no any problem for practicing it.

\section{Conclusion and Discussion}

Lesson study model has been used globally as a professional development model. According to related literature, lesson study contributes to students' achievement in direct and indirect way while it contributes to develop teachers' professional skills (Akerson et al., 2017; Akiba \& Wilkinson, 2016; Bjuland \& Mosvold, 2015; Güner \& Akyüz, 2017; Özaltun-Çelik \& Bukova-Güzel, 2016; Wood \& Cajkler, 2018). It is thought in the study that lesson study support English language teachers' both professional knowledge and experiences via analyzing and practicing of lesson study and assessment of lesson study after practice. Therefore, the study has analyzed whether lesson study affect students' English learning levels through teachers' developing professional knowledge and skills. Research results show that lesson study has increased students' learning levels significantly. Moreover, teachers stated that lesson study was highly beneficial and affected their professional development in a positive way. Therefore, they also stated that lesson study increased their students' learning levels indirectly and significantly. However, teachers agree that lesson study should be used as in-service teacher training approach that is used in other courses nationally. Lesson study is used for school-based professional development, and it includes many features. The most important ones of these features are teachers' interests, time for cooperation, principal support and action plan. Teachers should be eager to talk about their own opinions and practices, to work with their colleagues cooperatively, to try new ideas and change their teaching (Lewis \& Lee, 2017). In this manner, it can be said that using lesson study nationally and in other courses could contributes to both teachers' in-service professional development and students' learning. According to related literature, there are a lot of research about lesson study contributions to students' achievement especially in English and mathematics courses (Boran \& Tarım, 2016; Coşkun, 2017; Kıncal \& Beypınar, 2015; Koçak et al., 2018; Nashruddin \& Nurrachman, 2016; Saito et al., 2015). The results of the study about teachers' views about lesson study are parallel to international and national studies' results (Boran \& Tarım, 2016; Bozkuş et al., 2017; Cheung \& Wong, 2014; Gonzalez \& Deal, 2017; Günay, Yücel-Toy, \& Bahadır, 2016; Howell \& Saye, 2016).

Akiba, Murata, Howard \& Wilkinson (2019) state that teachers' cooperation affects their study in a limited way, 
but lesson study had a positive effect upon teachers' knowledge, expectations and their self-efficacy according to their study related to lesson study. However, Huang and Han (2015) also state that lesson study has increased teachers' teaching strategies and methods. Lewis and Tsuchida's (1998, p. 15) indicate, "Research lessons enable teachers to see different perspectives." Research lessons are real lesson studying with students. Research lessons are observed, saved and reported by other participant teachers. Thus teachers look at their own and other teachers from different critical perspective (Chichibu \& Kihara, 2013). Teachers take their roles as professional researchers especially in observation and meeting section of lesson study, and they observe both their own and other behaviors objectively (Roberts, 2010). Teachers focus on their own aim for that purpose they gather, and it enables teachers to limit personal or intentional critics. All participant should be willing to the process and overcome some obstacle like school management for enabling this environment. Teachers must have time to plan, observe and discuss their lesson in lesson study process. Therefore, it is important that school manager participate into lesson study process (Fujii, 2014; Lewis \& Lee, 2017). Moreover, it could be said that teachers have many problems about resources and support into the process, which managers do not participate. Designing lesson via discussing about it, analyzing and revising plans in practice and reflecting their own practices to each other are shown to contribute to make more produces in their teaching (Gutierez, 2015).

Goal setting for research lesson and planning research lesson and practice activities enable group cooperation and fidelity to group to develop. Cooperation is formed with not only participants but also schools, and thus, this cooperation makes self-criticism based culture (Droese, 2010). It is seen that lesson plan, research lesson, new teaching strategies and materials, which are formed with different views, contribute to students' learning levels and qualities and reasoning skills of students. Moreover, it could be inferred from the studies that students are transformed into much happier, participant and self-confident individuals, and however, they are more interested in learning. According to related literature, lesson study is seen to practice within different aspects (Cajkler et al., 2015). Thus, lesson study in English lesson practiced in the study can be said to contribute to both students' academic achievement and develop their self-efficacy. Therefore, it comes out that teacher take much more risk to develop students' learning and have more opportunities for problem solving and peer-learning according to related studies' results.

The study results show the outputs upon lesson study's contribution. According to these results, it could be suggested that lesson study should be used for in-service teacher training model for developing teaching quality and students' achievement. Lesson study in English lesson practiced in the study can be said to contribute to both students' academic achievement and develop their self-efficacy. Therefore, it comes out that teacher take much more risk to develop students' learning and have more opportunities for problem solving and peer-learning according to related studies' results.

\section{References}

Acat, B., \& Demiral, S. (2002). Sources of motivation in learning foreign language in Turkey. Educational Administration: Theory and Practice, 31, 311-329.

Akerson, V. L., Pongsanon, K., Rogers, M. A. P., Carter, I., \& Galindo, E. (2017). Exploring the use of lesson study to develop elementary preservice teachers' pedagogical content knowledge for teaching natüre of science. International Journal of Science and Mathematics Education, 15, 293-312. https://doi.org/10.1007/ s10763-015-9690-x

Akiba, M., \& Wilkinson, B. (2016). Adopting an international innovation for teachers Professional development: State and district approaches to lesson study in Florida. Journal of Teacher Education, 67(1), 74-93. https://doi.org/10.1177/0022487115593603

Aydın, B., Kızıltan, N., Öztürk, G., İpek, Ö. F., Yükselir, C., \& Beceren, S. (2017). Optional English prepatory programs after HEC 2016 regulation: Opinions of administrators on the current situation and problems. Anadolu University Journal of Education Faculty, 1(2), 1-14.

Bjuland, R., \& Mosvold, R. (2015). Lesson study in teachers education: learning from a challeging case. Teaching and Teacher Education, 52, 83-90. https://doi.org/10.1016/j.tate.2015.09.005

Boran, E., \& Tarım, K. (2016). The opinions of secondary school mathematics teachers about the lesson study. Turkish Journal of Compuuter and Mathematics Education, 7(1), 259-273. https://doi.org/10.16949/ turcomat.22182

Borko, H., \& Putnam, R. T. (1995). Expanding a teacher's knowledge base: A cognitive psychological perspective on professional development. In T. R. Guskey, \& M. Huberman (Eds.), Professional development in education: New paradigms and practices. New York: Teachers College Press. 
Bulle, N. (2011). Comparing OECD educational models through the prism of PISA. Comparative Education, 47(4), 503-521. https://doi.org/10.1080/03050068.2011.555117

Cajkler, W., Wood, P., Norton, J., Pedder, D., \& Xu, H. (2015). Teacher perspectives about lesson study in secondary school departments: A collaborative vehicle for professional learning and practice development. Research Papers in Education, 30(2), 192-213. https://doi.org/10.1080/02671522.2014.887139

Chichibu, T., \& Kihara, T. (2013). How Japanese schools build a professional learning community by lesson study. International Journal for Lesson and Learning Studies, 2(1), 12-25. https://doi.org/10.1108/ 20468251311290105

Coşkun, A. (2017). The application of lesson study in teaching English as a foreign langauge. İnönü University Journal of the Faculty of Education, 18(1), 151-162. doi:10.17679/inuefd.297845

Coşkun-Demirpolat, B. (2015). The challenge for Turkey's foreign language teaching, problems and solutions. Foundation of Political, Economic and Social Research, 131, 7-18.

Droese, S. (2010). Lesson study in the us: Is it a mechanism for individual and organizational change? A case study of three schools. Unpublished PhD thesis. U.S., Madison: The University of Wisconsin.

Ege, İ. (2011). Assessing the effectiveness of the activities based on european language portfolio (ELP) in the second foreign language (German) teaching. Unpublished doctoral dissertation. Selçuk University, Konya.

Fujii, T. (2014). Implementing Japanese lesson study in foreign countries: Misconceptions revelad. Mathematics Teacher Education and Development, 16(1), 2-18.

Grosso de Leon, A. (2001). Higher education's challenge: New teacher education models for a new century. New York: Carnegie Corporation of New York.

Güner, P., \& Akyüz, D. (2017). The quality of prospective teachers' mathematical noticing in the context of lesson study. Ondokuz Mayis University Journal of Faculty of Education, 36(1), 47-81. https://doi.org/10.7822/omuefd.327389

Gürgür, H. (2016). Action research. A. Saban \& A. Ersoy (Ed.) In Qualitative Research Designs in Education (pp. 3-50). Ankara: An1 Publishing.

Halvorsen, A. L., \& Lund, A.K. (2013). Lesson study and history education. The Social Studies, 104(3), 123-129. https://doi.org/10.1080/00377996.2012.698326

Haznedar, B. (2004). Primary foreign language learning and curriculum development in Turkey. Boğaziçi University Journal of Education, 21(2), 15-29.

Işı1k, A. (2008). Where do the false in our foreign language education originate? Journal of Language and Linguistic Studies, 4(2), 15-26.

Kıncal, R. Y., \& Beypınar, D. (2015). The effects of "lesson study" implementation to professional development of mathematics teachers and development of learning process. Mehmet Akif Ersoy University Journal of Education Faculty, 33, 186-210.

Koçak M., Ozan C., İleritürk D., Buran O., Soylu Y., \& Kincal R. Y. (2018, April). Increasing students' mathematic learning via lesson study approach. Paper presented at the 27th International Congress on Educational Sciences, Antalya, Turkey.

Lewis, C., \& Tsuchida, I. (1998). A Lesson Is Like A Swiftly Flowing River. American Educator, 22(4), 14-17 ve 50-52.

Lewis, C. C., \& Lee, C. (2017). The global spread of lesson study. In M. Akiba, \& G. LeTendre (Eds.), International Handbook of teacher quality and policy (pp. 185-195). New York: Routledge. https://doi.org/10.4324/9781315710068-13

Lucenario, J. L. S., Yangco, R. T., Punzalan, A. E., \& Espinosa, A. A. (2016). Pedagogical content knowledge-guided lesson study: Effects on teacher competence and students' achievement in chemistry. Education Research International, 1-9. https://doi.org/10.1155/2016/6068930

Luukkainen-Harju, H., Vettenranta, J., Soivio-Ouakrim, N., \& Bernelius, V. (2016). Differences between students' PISA reading literacy scores and grading for mother tongue and literature at school: A geostatistical analysis of the Finnish PISA 2009 data. Education Inquiry, 7(4), 463-479. https://doi.org/10.3402/edui.v7.29413

Midgette, A. J., Ilten-Gee, R., Wong-Powers, D., Murata, A., \& Nucci, L. (2018). Using lesson study in teacher 
Professional development for domain-based moral education. Journal of Moral Education. https://doi.org/10.1080/03057240.2018.1445982

Miles, M. B., \& Huberman, A. M. (2015). Qualitative data analysis (Trans. Ed. S. A. Altun \& A. Ersoy). Ankara: Pegem Academy Publishing.

Nami, F., Marandi, S. S., \& Sotoudehnama, E. (2016). CALL teacher professional growth through lesson study practice: An investigation into EFL teachers' perceptions. Computer Assisted Language Learning, 29(4), 658-682. https://doi.org/10.1080/09588221.2015.1016439

Nashruddin, W., \& Nurrachman, D. (2016). The implementation of lesson study in English language learning: A case study. Dinamika Ilmu, 16(2), 169-179. https://doi.org/10.21093/di.v16i2.356

Oflaz, A. (2015). German vocabulary teaching in traditional and alternative foreign language teaching methods. International Periodical for the Languages, Literature and History of Turkish or Turkic, 10(3), 695-712.

Ono, Y., \& Ferreira, J. (2010). A case study of continuing teachers Professional development through lesson study in South Africa. South African Journal of Education, 30, 59-74.

Özaltun-Çelik, A., \& Bukova-Güzel, E. (2016). A mathematics teacher's questioning approaches for revealing students' thinking during lesson study. Turkish Journal of Computer and Mathematics Education, 7(2), 365-392. https://doi.org/10.16949/turcomat.93160

Özdemir-Ateş, E. (2006). Reasons for the Spread of English Education in Turkey. Mersin University Journal of the Faculty of Education, 2(1), 28-35.

Phillips, J. (2003). Powerful learning: Creating learning communities in urban school reform. Journal of Curriculum and Supervision, 18(3), 240-258.

Roberts, M. (2010). Lesson study: Professional development and its impact on science teacher self-efficacy. Unpublished $\mathrm{PhD}$ thesis. New York, USA: Columbia University.

Sağlam, M., Özüdoğru, F., \& Çıray, F. (2011). The European Union education policies and their effects upon Turkish education system. Van Yüzüncü Yll University Journal of Education, 8(1), 87-109.

Saito, E., Harun, I., Kuboki, I., \& Tachibana, H. (2015). Indonesian lesson study in practice: Case study of Indenesian mathematics and science teachers education project. Journal of In-service Education, 32(2), 171-184. https://doi.org/10.1080/13674580600650872

Schipper, T., Goei, S. L., Vries, S., \& van Veen, K. (2018). Developing teachers' self-efficacy and adaptive teaching behaviour through lesson study. International Journal of Educational Research, 88, 109-120.

Stepanek, J., Appel, G., Leong, M., Mangan, M. T., \& Mitchell, M. (2007). Leading lesson study. California, USA: Corwin Press.

Vogt, F., \& Rogella, M. (2009). Developing adaptive teaching competency through coaching. Teaching and Teacher Education, 25(8), 1051-1060.

Teddlie, C., \& Tashakkori, A. (2009). Foundations of mixed methods research: Integrating quantitative and qualitative approaches in the social and behavioral sciences. Thousand Oaks, CA: Sage.

Wood, P., \& Cajkler, W. (2018). Lesson study: A collaborative approach to scholarship for teaching and learning in higher education. Journal of Further and Higher Education, 42(3), 313-326. https://doi.org/10.1080/ 0309877X.2016.1261093

\section{Copyrights}

Copyright for this article is retained by the author(s), with first publication rights granted to the journal.

This is an open-access article distributed under the terms and conditions of the Creative Commons Attribution license (http://creativecommons.org/licenses/by/4.0/). 